\title{
INDUCTION OF PECTINASES IN ACROCYLINDRIUM
}

\author{
HITOSHI KIMURA AND SHOJI MIZUSHIMA \\ Department of Agricultural Chemistry, \\ Faculty of Agriculture, Nagoya University, Chikusa-ku, Nagoya 464, Japan
}

(Received September 13, 1973)

\begin{abstract}
Galacturonic acid, and oligo- and poly-galacturonic acids induced the synthesis of endopolygalacturonase, exopolygalacturonase, pectinesterase, and enzymes responsible for galacturonic acid metabolism in astrain of Acrocylindrium. These enzymes had similar characteristics for inducer specificity, time curves of induction, and catabolite repression. In the absence of inducers, mutants constitutive for exopolygalacturonase failed to synthesize endopolygalacturonase, pectinesterase, and enzymes responsible for galacturonic acid metabolism. However, the rate of the induced synthesis on galacturonic acid of endopolygalacturonase and pectinesterase in mutants was much faster than that in the wild-type strain. A relationship between the induced synthesis of these enzymes was discussed.
\end{abstract}

Endopolygalacturonase (endoPG) (EC 3.2.1.15), exopolygalacturonase (exoPG) (EC 3.2.1.15), and pectinesterase (PE) (EC 3.1.1.11) were induced simultaneously in a strain of Acrocylindrium grown on pectin as a carbon source (1-3). Therefore, a question arose whether the induction of these enzymes was under the same genetic control or not. Although some experiments have suggested the occurrence of the so-called operon in fungi $(4,5)$, details of the regulatory mechanism of enzyme induction in eukaryotic cells remain unclear.

In the present work, a comparison was made on the induction of these pectinases and enzymes responsible for galacturonic acid metabolism.

\section{MATERIALS AND METHODS}

Organism and cultivation. A strain of Acrocylindrium (A2-1-1) was obtained from the National Institute of Agricultural Sciences, Tokyo, Japan. The growth medium contained $(\mathrm{g} / 100 \mathrm{ml})$ : Glucose, $2 ; \mathrm{NH}_{4} \mathrm{NO}_{3}, 1 ; \mathrm{KH}_{2} \mathrm{PO}_{4}, 0.5 ; \mathrm{MgSO}_{4}$. $7 \mathrm{H}_{2} \mathrm{O}, 0.05$; yeast extract (Oriental Yeast Co., Tokyo), 0.2; pH 5.6. Cultures were grown in $500-\mathrm{ml}$ flasks containing $100 \mathrm{ml}$ of the medium on a reciprocal shaker (136 strokes $/ \mathrm{min})$ at $30^{\circ}$ for $48 \mathrm{hr}$. A linear growth was obtained under 
the conditions. Usually about $60 \%$ of the maximum growth was achieved after a 48-hr cultivation.

Preparation of oligogalacturonic acids and oxidized oligogalacturonic acids. Di-, tri-, and tetra-galacturonic acids (2GA, 3GA, and 4GA, respectively) were prepared by the use of endoPG from Saccharomyces fragilis (6), a gift from J. Ozawa, and their oxidized forms (ox2GA, ox3GA, and ox4GA, respectively) were prepared by the method of PATEL and PHAFF (7). In oxidized oligogalacturonic acids, galacturonic acid residue at reducing end had been converted into mucic acid.

Galacturonic acid (GA) and polygalacturonic acid (PGA) were products from Sigma Chemical Co., St. Louis, Missouri, U.S.A. The method for the preparation of oxidized PGA (oxPGA) was the same as that of oxidized oligogalacturonic acids.

Induction experiment. Cells were collected by centrifugation at $6000 \times g$ for $10 \mathrm{~min}$ and washed three times with an equal volume of $0.05 \mathrm{M} \mathrm{KCl}-\mathrm{HCl}$ buffer ( $\mathrm{pH}$ 2.5). The cells ( $40 \mathrm{mg}$ dry wt.) were then suspended in $10 \mathrm{ml}$ of the same buffer containing $20 \mathrm{mg}$ of the inducer and $30 \mathrm{mM}^{\circ} \mathrm{NH}_{4} \mathrm{Cl}$ which stimulated the induction of endoPG (see Fig. 10), and induction was made at $30^{\circ}$ on a shaker (136 strokes/min). A portion of the incubation mixture (1 or $2 \mathrm{ml}$ ) was taken out at time intervals and used for enzyme assays.

Enzyme assay. EndoPG activity was assayed by measuring the decrease in viscosity of PGA and expressed in VR units. One VR unit is defined as the amount of enzyme which reduces the viscosity of PGA by $50 \%$ in $10 \min (1)$. ExoPG in cells was assayed as follows: The cells ( $8 \mathrm{mg}$, dry wt.) were suspended in $3 \mathrm{ml}$ of $0.05 \mathrm{M} \mathrm{KCl}-\mathrm{HCl}$ buffer ( $\mathrm{pH} 2.5$ ) containing $3 \mathrm{mg}$ of $3 \mathrm{GA}$ and $30 \mu \mathrm{g}$ of cycloheximide. $3 \mathrm{GA}$ is not hydrolyzed by endoPG but by exoPG $(1,3)$. After 2 -hr incubation at $30^{\circ}, 3 \mathrm{GA}$ remaining in the reaction mixture was determined by the carbazole-sulfuric acid method (8). The rate of consumption of $3 \mathrm{GA}$ was constant during this period. The enzyme activity of exoPG is expressed as $\mu \mathrm{mol}$ of 3GA consumed per min. Activity of PE was assayed by measuring the $\mathrm{pH}$ decrease and expressed in PE units. One PE unit is defined as the amount of the enzyme which changes $0.1 \mathrm{pH}$ unit at $\mathrm{pH} 7.5$ per min at $30^{\circ}(2)$. Protein was estimated by the method of Lowry et al. (9), with egg albumin (Katayama Kagaku Co.) as reference protein.

Isolation of exoPG-constitutive mutants. Glucose-grown cells were washed three times and suspended in an equal volume of distilled water, and filtered through absorbent cotton to remove mycelia. Spores in the filtrate were suspended in distilled water to a density of $4 \times 10^{6}$ spores per $\mathrm{ml}$. A $5-\mathrm{ml}$ spore suspension was placed in a petri dish and irradiated for $4 \mathrm{~min}$ at a distance of $40 \mathrm{~cm}$ under ultraviolet lamp (15 watt) with gentle agitation of the suspension. The irradiated spores $(0.1 \mathrm{ml})$ were incubated in $5 \mathrm{ml}$ of the medium containing $0.1 \%$ ox $3 \mathrm{GA}, 1 \% \mathrm{NH}_{4} \mathrm{NO}_{3}, 0.5 \% \mathrm{KH}_{2} \mathrm{PO}_{4}$, and $0.05 \% \mathrm{MgSO}_{4} \cdot 7 \mathrm{H}_{2} \mathrm{O}(\mathrm{pH} 5.6)$ on a 
shaker for 5 days. After the significant growth was observed, mycelia were removed by filtration. Spores in the filtrate were diluted, plated on the growth medium (glucose medium) with $2 \%$ agar, and incubated for $48 \mathrm{hr}$. Colonies grown on glucose-agar plates were replica-plated on the ox3GA medium. Colonies grown in the latter agar medium were isolated.

\section{RESULTS}

Effect of carbon source on induction of pectinases during growth

Cells were aerobically grown for 4 days in the growth medium in which glucose was replaced by other carbon sources. Carbon sources tested were as follows: Tartronic acid, xylose, arabinose, rhamnose, mannose, mannitol, dulcitol, mucic acid, glucuronic acid, galactose, fructose, glucose, lactose, sucrose, maltose, raffinose, xylan, inuline, starch, GA, PGA, and pectin. Growth occurred in cultures supplied with xylose, arabinose, mannose, galactose, fructose, glucose, sucrose, maltose, raffinose, xylan, starch, GA, PGA, or pectin. After the separation of mycelia from culture fluid by centrifugation, endoPG and PE activities in the culture fluid were determined. These enzymes were formed only in the culture containing GA, PGA, or pectin as a carbon source.

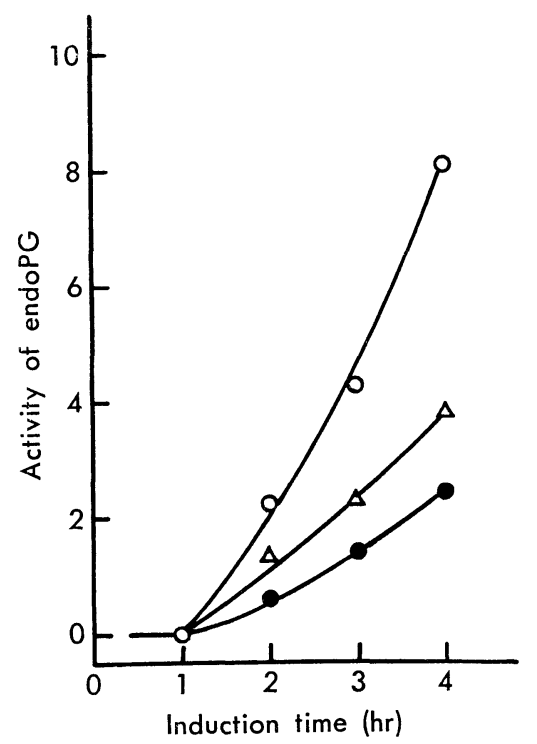

Fig. 1. Effect of $\mathrm{pH}$ on induction of endoPG.

Glucose-grown cells (40 mg dry wt.) were harvested from a 100-ml culture and washed three times with distilled water. Cells were suspended in $10 \mathrm{ml}$ of following buffers containing $20 \mathrm{mg}$ of $\mathrm{GA}$ and $30 \mathrm{mM}$ of $\mathrm{NH}_{4} \mathrm{Cl}$ : (O) $0.05 \mathrm{M} \mathrm{KCl}-\mathrm{HCl}$ buffer of $\mathrm{pH} 2.5 ;(\triangle) 0.05 \mathrm{M}$ citric acid- $\mathrm{Na}_{2} \mathrm{HPO}_{4}$ buffer of $\mathrm{pH} 5.0 ;(\bullet) 0.05 \mathrm{M}$ citric acid- $\mathrm{Na}_{2} \mathrm{HPO}_{4}$ buffer of $\mathrm{pH} 7.0$. Incubations were made at $30^{\circ}$ on a shaker. 
Effect of $p H$ on endoPG induction on $G A$

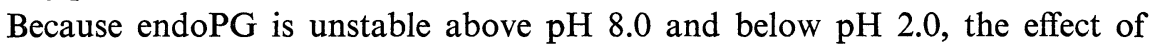

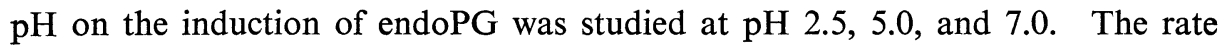
of induction was the highest at $\mathrm{pH} 2.5$ (Fig. 1).

\section{Induction of pectinases}

The time course of the induction of pectinases on pectic substance was studied with washed cells. As shown in Fig. 2, the time curves were quite similar to each other for three enzymes. EndoPG, exoPG, and PE were induced by GA and its oligomer as well as PGA, while oxidized oligogalacturonic acid and oxPGA were not inducers for any of these enzymes. The induction of these enzymes by GA occurred after a lag period of $1 \mathrm{hr}$, while the induction by other inducers occurred after that of $2 \mathrm{hr}$.
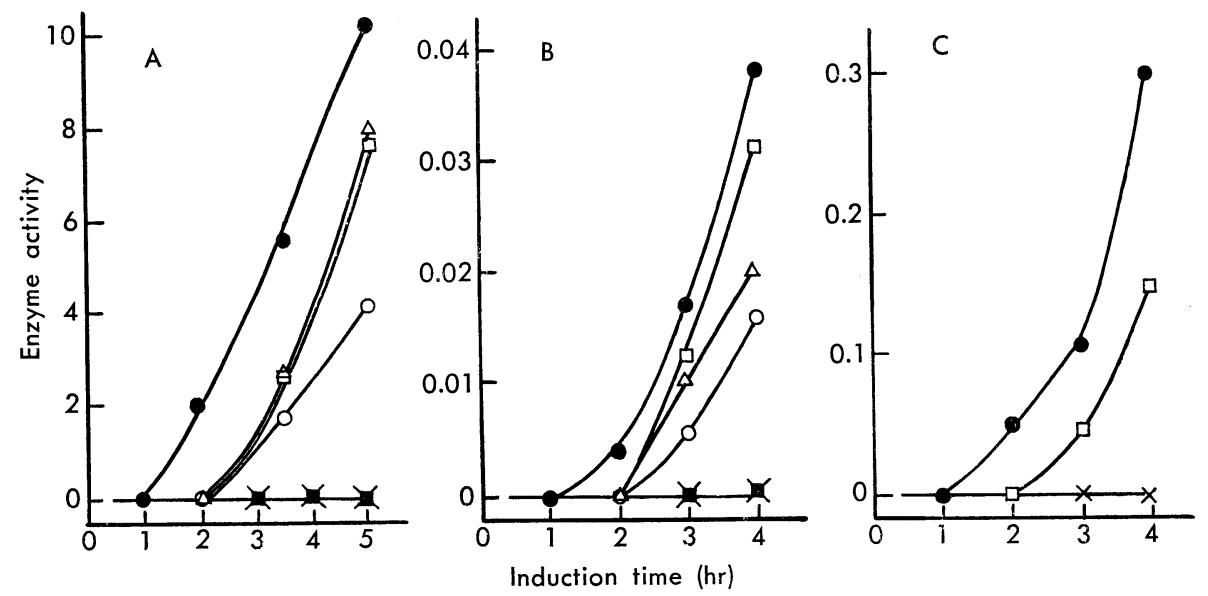

Fig. 2. Time curves of induction of pectinases.

The induction was carried out under conditions described in the text. At the indicated time intervals, a $2.0-\mathrm{ml}$ cell suspension was removed and its enzyme content was assayed. A, EndoPG; B, ExoPG; C, PE; Each experiment (A, B, C) was made independently. Inducers added were: ๑, GA; $\bigcirc, 2 \mathrm{GA} ; \triangle, 3 \mathrm{GA}, 4 \mathrm{GA}$; $\square, \mathrm{PGA} ; \times$, oxGA, $\mathbf{E}$, ox2GA, ox3GA, ox4GA, oxPGA.

\section{Effect of $G A$ concentration on endoPG induction}

The GA concentration changed neither the initial rate nor the lag period of the enzyme synthesis, but it changed the total amount of enzyme formed (Fig. 3). The possibility that some impurities in the GA preparation might be a true inducer was examined. Recrystallization of GA from ethanol solution did not make any difference in the requirement of GA for the induction. 


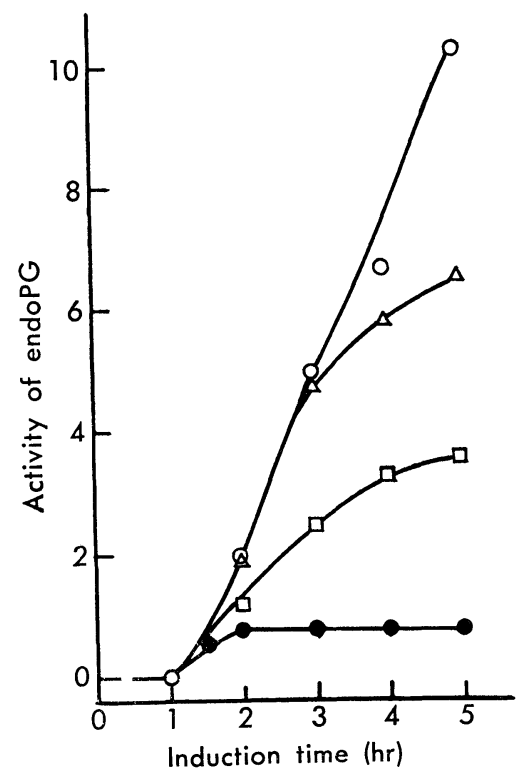

Fig. 3. Effect of GA concentration on induction of endoPG.

GA concentration: $\bigcirc 10^{-2} \mathrm{M} ; \triangle 6 \times 10^{-3} \mathrm{M} ; \square 3 \times 10^{-3} \mathrm{M} ; \bullet 10^{-3} \mathrm{M}$.

\section{Metabolism of $G A$ in cells}

The metabolism of GA in the induced cells was inhibited by malonic acid or arsenic acid, inhibitors for TCA cycle. These inhibitors also inhibited the induction of endoPG on GA at the same concentration. This result shows that GA was used as an energy source for the induction as well as an inducer.

As shown in Fig. 4, enzymes responsible for GA metabolism was also inducible. GA and PGA induced the pathway after 1 and $2 \mathrm{hr}$ of lag period, respective$1 \mathrm{y}$, as in the case of three pectinases.

\section{No breakdown of PGA and oligogalacturonic acids by noninduced cells}

As shown in Fig. 2, the induction on GA was always initiated $1 \mathrm{hr}$ in advance of the induction on other inducers. Therefore, the possibility that oligogalacturonic acids and PGA were hydrolyzed in advance of the induction to give GA which might be a true inducer was examined. The activities of exoPG and endoPG were measured on the glucose-grown cells and its culture filtrate, respectively. To prevent the induction of these enzymes during enzyme assay, cycloheximide was added to reaction mixtures which contained the cells. There was no detectable activity of the enzymes in either the cells or the culture fluid.

The absence of such enzymes that could hydrolyze PGA or oligogalacturonic acids in advance of induction was also supported by the following fact. As shown in Fig. 2, oxPGA is not an inducer. If the presence of a small amount of an 


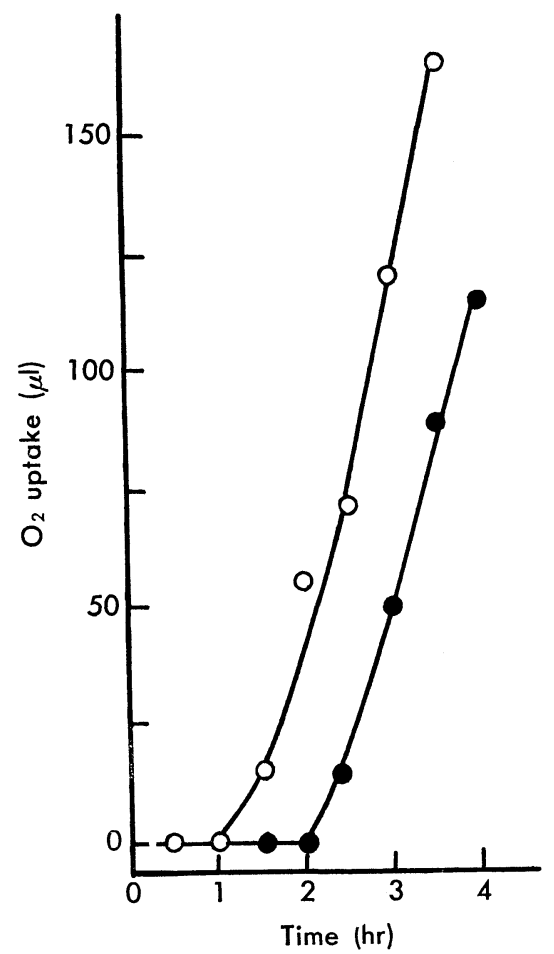

Fig. 4. Induced synthesis of oxidizing activity for GA and PGA in glucosegrown cells.

Cells were harvested from $100-\mathrm{ml}$ cultures and suspended in $0.05 \mathrm{M} \mathrm{KCl}-\mathrm{HCl}$ buffer of $\mathrm{pH} 2.5$. The oxygen uptake by whole cells was measured at $30^{\circ}$ in a Warburg apparatus. Each Warburg flask contained; $4 \mathrm{mg}$ (dry wt.) of cells in $1.2 \mathrm{ml}$ of $0.05 \mathrm{M}$ $\mathrm{KCl}-\mathrm{HCl}$ buffer of $\mathrm{pH} 2.5$ in the main compartment; $4 \mathrm{mg}$ of GA or PGA in $0.2 \mathrm{ml}$ of $\mathrm{H}_{2} \mathrm{O}$ in the side arm; $0.2 \mathrm{ml}$ of $20 \% \mathrm{KOH}$ in the center well. After the vessels were shaken for $30 \mathrm{~min}$ at $30^{\circ}$, experiments were started by adding GA or PGA into the main flask. All values were corrected for endogeneous respiration. O, GA; •, PGA.

enzyme like the endoPG or the exoPG is responsible for the induction of pectinases by converting PGA to GA, oxPGA should have also been an inducer. These facts, together with the fact which will be described later relating to exoPG constitutive mutants, support the idea that PGA and oligogalacturonic acids are inducers.

\section{Hydrolysis of oxPGA by exoPG in intact cells}

To be an inducer for enzyme synthesis, PGA has to be incorporated directly into the cells. In order to prevent completely the induction of endoPG, cycloheximide was added to the reaction mixture and oxPGA, which is not an inducer, was used as a substrate. As shown in Fig. 5, oxPGA was hydrolyzed by the cells induced on GA. The fungus seems to possess exoPG in cytoplasmic space 


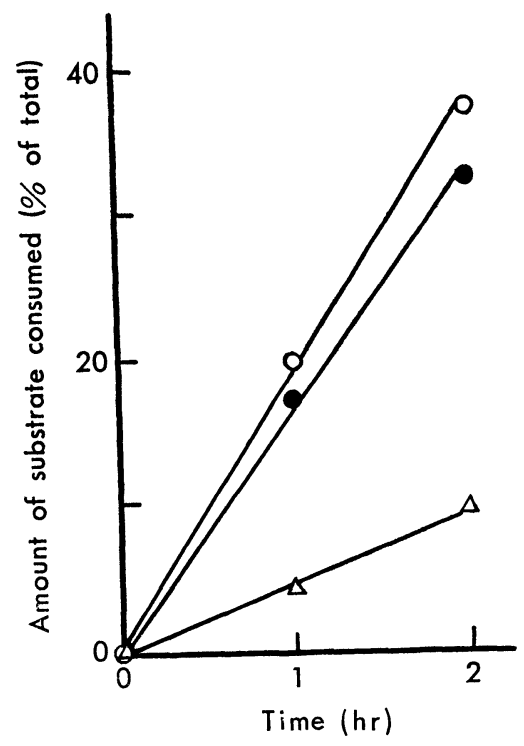

Fig. 5. Degradation of oligo- and poly-galacturonic acids by GA-induced cells. Induction was made under the conditions for induction experiment on GA for $4 \mathrm{hr}$. Induced cells thus obtained were washed 3 times with distilled water and were transferred to $\mathrm{KCl}-\mathrm{HCl}$ buffer $(10 \mathrm{ml})$ containing $10 \mathrm{mg}$ of $3 \mathrm{GA}$, ox3GA, or oxPGA, and $100 \mu \mathrm{g}$ of cycloheximide. Amount of uronic acids remaining in the medium was estimated by the carbazole-sulfuric acid method (8). $0,3 \mathrm{GA} ; \bullet$, ox3GA; $\triangle$, oxPGA.

and exoPG was only an enzyme found so far which can hydrolyze oxPGA in the cells (3). Although there was no direct evidence that PGA is directly incorporated into the cells, the result suggests that PGA as well as oxPGA is incorporated directly into the cells. However the possibility that only induced cells can incorporate PGA has not been ruled out. The hydrolysis of ox3GA was also observed in the cells (Fig. 5).

Properties of constitutive mutant for exoPG

As enzymes related to the metabolism of pectin showed the same inducer specificity, the possibility that the synthesis of these enzymes is under the same genetic control was indicated. To investigate the possibility, five constitutive mutants for exoPG synthesis were selected independently. As ox3GA does not induce either endoPG or exoPG and is not hydrolyzed by endoPG, a mutant which can grow on ox $3 \mathrm{GA}$ as a sole carbon source must be a constitutive strain for exoPG synthesis.

As shown in Fig. 6, one of these mutants (No. 1) synthesized exoPG in the absence of an inducer. The mutant also synthesized exoPG on ox3GA, whereas the wild type strain did not. All other mutants isolated showed the same properties. The synthesis of endoPG and PE was then examined in the mutants. All 


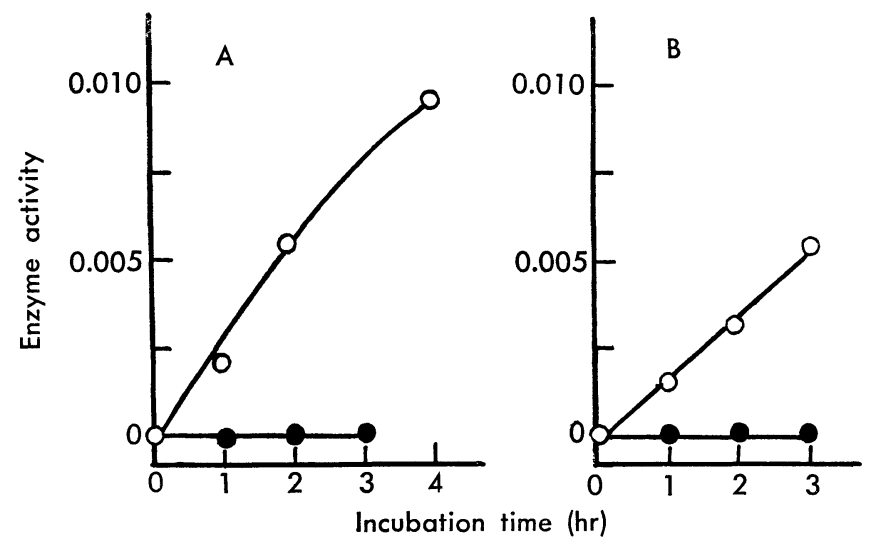

Fig. 6. Synthesis of exoPG by mutant (No. 1) and wild type strain.

Glucose-grown cells ( $40 \mathrm{mg}$ dry wt.) were washed three times with distilled water and suspended in $10 \mathrm{ml}$ of $\mathrm{KCl}-\mathrm{HCl}$ buffer containing $10 \mathrm{mg}$ of casamino acids (A) or $20 \mathrm{mg}$ of ox3GA and $30 \mathrm{~mm}$ of $\mathrm{NH}_{4} \mathrm{Cl}$ (B). Incubations were made at $30^{\circ}$ on a shaker. A 2.0-ml suspension was removed at indicated time and exoPG content was assayed. O, Mutant (No. 1); •, Wild type strain.
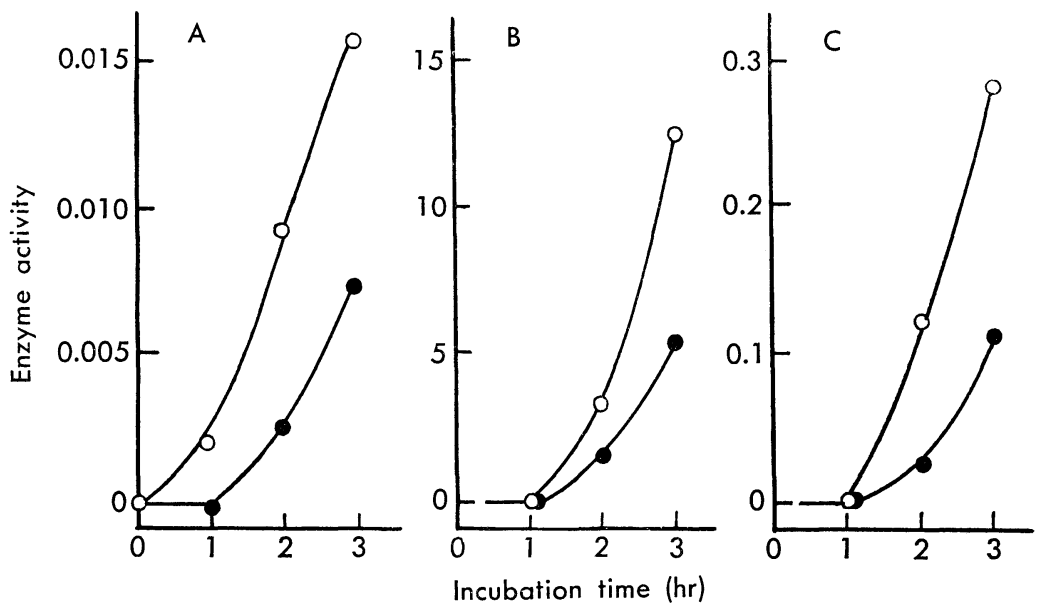

Fig. 7. Synthesis of pectinases by mutant (No. 1) and wild type strain.

Incubations with GA were carried out under the conditions for induction experiment, and enzyme contents were assayed. A, ExoPG; B, EndoPG; C, PE. O, Mutant (No. 1); $\bullet$, Wild type strain.

mutants failed to synthesize both enzymes in the absence of inducers. The synthesis of these enzymes was also not observed on ox3GA. As the mutants have exoPG constitutively, they can hydrolyze ox3GA to give GA, which in turn could have induced endoPG and PE. This result may be explained by the idea that the 
rate of GA release from ox3GA by exoPG in the cells was too low compared with that of GA metabolism to accumulate enough GA to induce these enzymes. Figure 7 shows the induction of endoPG and PE on GA by a mutant and the wild type strain. The rate of synthesis of both enzymes by the mutant was much faster than that by the wild type strain. The phenomena were also observed in all other mutants.

\section{Oxidation of $G A$ by mutant}

There was an explanation for the stimulation of the synthesis of endoPG and PE in the mutant. If the synthesis of enzymes responsible for GA metabolism is controlled by the same regulator gene as that of exoPG, the synthesis of these enzymes would also be constitutive in the mutant. Therefore, the synthesis of enzyme induced on GA would be stimulated by the faster GA metabolism; i.e., a greater production of energy. The constitutive synthesis of enzymes of GA metabolism was studied in the mutant. After the incubation in casamino acids, the oxidation of GA was examined by a mutant (No. 1) and the wild type strain. However, no detectable oxidation of GA was observed by either of the strains.

\section{Effect of glucose and other carbon sources on the synthesis of enzymes}

Like most inducible enzymes, the induction of pectinases is subject to catabolite repression. As shown in Fig. 8, the addition of glucose immediately re-

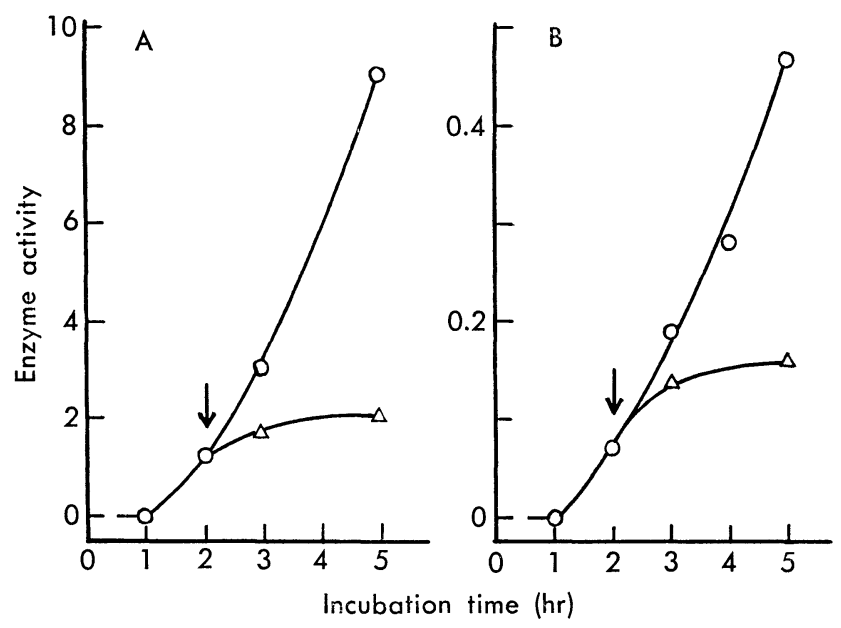

Fig. 8. Transient repression of pectinases by glucose in wild type strain.

The induction by GA was carried out using 2 volumes of standard reaction mixture for induction experiment. At the point indicated by arrows, the incubation mixture was divided into two equal portions. Glucose was added to one portion and incubation was continued. A, EndoPG; B, PE. O, No additions; $\triangle$, Glucose added to $2 \times 10^{-2} \mathrm{M}$. 


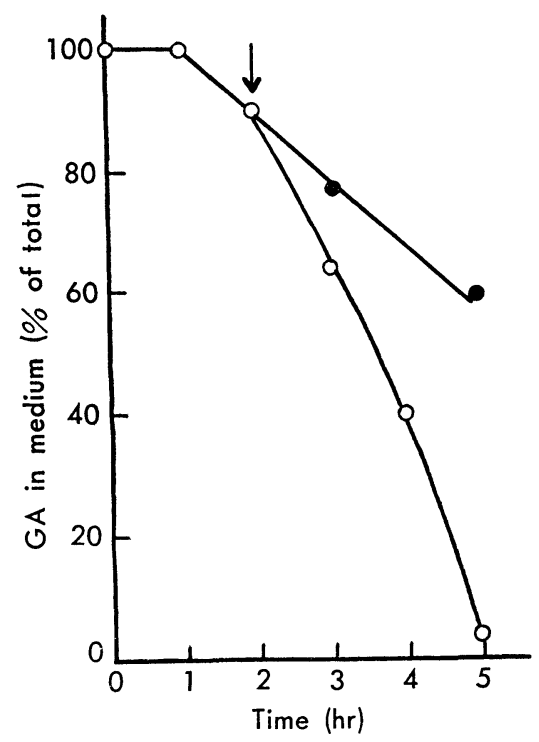

Fig. 9. Effect of glucose on the rate of consumption of GA.

Incubation with GA was carried out using 2 volumes of standard reaction mixture for induction experiment. At the time indicated by an arrow, the incubation mixture was divided into two equal portions. Glucose was added to one portion and incubation was continued. Amount of GA remaining in the medium was estimated by the carbazole-sulfuric acid method (8). $\bigcirc$, No additions; $\bullet$, Glucose added to $2 \times 10^{-2} \mathrm{M}$.

pressed the induction of pectinases, while the consumption of GA by the preformed system in the cells was not affected by glucose. Following substances were also found to repress the induced synthesis of pectinases on GA: Fructose, mannose, xylose, glycerol, malic acid, $\alpha$-ketoglutaric acid, pyruvic acid, succinic acid, fumaric acid, and acetic acid. Glucose also repressed the induced synthesis of enzymes responsible for GA metabolism (Fig. 9). It was also inhibitory in the synthesis of exoPG in the constitutive mutant.

The effect of amino acids on pectinase induction was also tested. Glycine, valine, glutamic acid, and casamino acids neither repressed nor stimulated endoPG and PE synthesis on GA. Lysine and ammonium chloride stimulated the synthesis of these enzymes on GA.

The effect of ammonium chloride on catabolite repression was further studied on the induction of endoPG. As shown in Fig. 10, ammonium chloride overcame the repression by $a$-ketoglutaric acid. Glutamic acid did not show any effect on the enzyme induction. Fig. 11 shows the effect of ammonium chloride and $a$ ketoglutaric acid on the induced uptake of GA. $\alpha$-Ketoglutaric acid completely repressed the induction and ammonium chloride abolished the repression as in the case of endoPG induction. The repression by pyruvic acid was also reversed by ammonium chloride. 


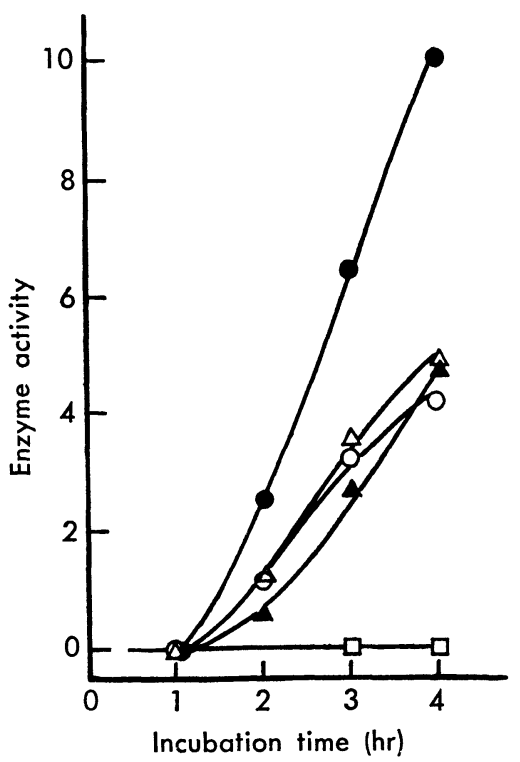

Fig. 10. Effect of $\alpha$-ketoglutaric acid, $\mathrm{NH}_{4} \mathrm{Cl}$, and glutamic acid on induction of endoPG.

Induction experiment was carried out as described in the text. At zero time, GA was added with following substances $\left(6 \times 10^{-2} \mathrm{M}\right): \mathrm{O}$, None; $\mathrm{O} \mathrm{NH}_{4} \mathrm{Cl} ; \triangle$, Glutamic acid; $\Delta, \alpha$-Ketoglutaric acid and $\mathrm{NH}_{4} \mathrm{Cl} ; \square, \alpha$-Ketoglutaric acid.

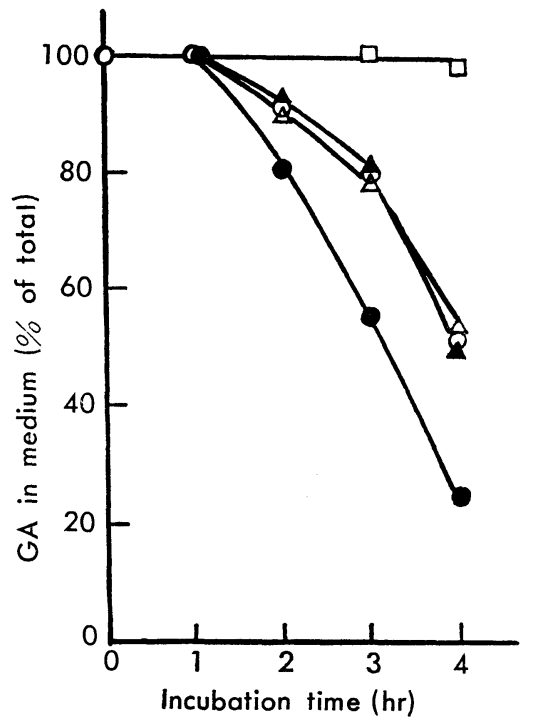

Fig. 11. Effect of $\alpha$-ketoglutaric acid, $\mathrm{NH}_{4} \mathrm{Cl}$, and glutamic acid on induced uptake of GA.

The experiment was carried out using the same reaction mixtures as those in Fig. 9. At the indicated time intervals, a $2.0-\mathrm{ml}$ suspension was taken out and the amount of GA was estimated by the carbazole-sulfuric acid method (8). Symbols are the same as those in Fig. 9. 


\section{DISCUSSION}

Lag periods of the induction of pectinases on oligogalacturonic acids or PGA were $1 \mathrm{hr}$ longer than that on GA. This fact suggested that oligogalacturonic acids and PGA were hydrolyzed in advance of the induction to give GA which might be a true inducer. The suggestion was, however, not supported by the following findings: (1) The cells used for induction experiments did not produce any detectable amount of pectinases until an inducer was added. However, there still was the possibility that a very small amount of GA, which could be produced from oligogalacturonic acids or PGA by an undetectable amount of enzyme, was sufficient to induce these enzymes. A mutant constitutive for exoPG could not induce endoPG or PE on ox3GA which must be hydrolyzed to give GA in the cells. This result suggests that a small amount of GA hardly induces these enzymes. (2) OxPGA which could be hydrolyzed to give GA by enzymes like endoPG or exoPG was ineffective as an inducer.

The wide-spread occurrence of functionally related clusters of genes in bacterial cells is now well established. In contrast, the occurrence of such systems in eukaryotic cells remains unknown. PATEMAN and Cove (10) have reported that enzymes in nitrate reduction were induced by nitrate, and the induction of these enzymes was repressed by a single mutation. However, they showed the dispersed location of the genes for these enzymes. Recent study by RiNES et al. (5) has shown an evidence for gene cluster in Neurospora coding for five enzymes which form a complex and catalyze steps two through six in the aromatic synthetic pathway. However, the evidence which supports the existence of an operon-like system has not been found.

In Acrocylindrium, the synthesis of endoPG, exoPG, PE, and enzymes of GA metabolism was induced by the same substances, and the time curves of the induction on each inducer were quite similar over all the enzymes so far tested. These facts suggested the possible existence of a coordinated regulatory mechanism among the synthesis of these enzymes. However, the constitutive synthesis of endoPG, PE, and enzymes of GA metabolism was not observed in exoPG constitutive mutants. This fact shows that a regulatory system controlling the synthesis of these enzymes, if any, is different from the repressor-operator model of JACOB and MONOD (11) in bacteria.

As shown in Fig. 7, however, in all exoPG constitutive mutants so far isolated, the rate of the induced synthesis of endoPG and PE by GA was stimulated by about 2-fold over the wild type strain. The fact may be a reflection of some regulatory mechanism which controls the synthesis of these enzymes.

The synthesis of all the enzymes studied in the present work was subject to a catabolite repression. In Escherichia coli, the catabolite repression of $\beta$-galactosidase by glucose was relieved by cyclic AMP. In a preliminary experiment with Acrocylindrium, $5 \times 10^{-3} \mathrm{M}$ cyclic AMP did not bring any relief of the catabolite repression of pectinases caused by $2 \times 10^{-2} \mathrm{M}$ glucose (Kimura and Mizushima, 
unpublished data). The reason has not been examined. In Neurospora it has been found that cyclic AMP did not relieve the catabolite repression of protease synthesis (12).

Authors express their thanks to H. Kobayashi for the isolation of mutants.

\section{REFERENCES}

1) H. Kimura, F. Uchino, and S. Mizushima, J. Gen. Microbiol., 74, 127 (1973).

2) H. Kimura, F. Uchino, and S. Mizushima, Agr. Biol. Chem. (Tokyo), 37, 1209 (1973).

3) H. Kimura, and S. Mizushima, Agr. Biol. Chem. (Tokyo), 37, 2589 (1973).

4) M. Piotrowska, M. Sawicki, and P. Weglenski, J. Gen. Microbiol., 55, 301 (1969).

5) H. Rines, M. E. Case, and N. Giles, Genetics, 61, 789 (1969).

6) C. Hatanaka, and J. Ozawa, Agr. Chem. Soc. Japan, 40, 98 (1966), in Japanese.

7) D. S. Patel, and H. J. PhafF, J. Biol. Chem., 234, 237 (1959).

8) T. Matsumura, In Tatō Seikagaku (Polysaccharide Biochemistry), Vol. 1, ed. by A. Suzuki, T. Matsumura, and I. Yamashina, Kyoritsu Shuppan Co., Tokyo (1969), p. 53.

9) O. H. Lowry, N. J. Rosebrough, A. L. Farr, and R. J. Randall, J. Biol. Chem., 193, 265 (1951).

10) J. A. Pateman, and D. J. Cove, Nature, 215, 1234 (1967).

11) F. JACOB, and J. MonOD, J. Mol. Biol., 3, 318 (1961).

12) H. DRUCKER, J. Bacteriol., 110, 1041 (1972). 